\title{
Air Pollutant Characterization in Tula Industrial Corridor, Central Mexico, during the MILAGRO Study
}

\author{
G. Sosa, E. Vega, E. González-Avalos, V. Mora, and D. López-Veneroni \\ Investigación y Posgrado, Instituto Mexicano del Petróleo, Eje Central Lázaro Cárdenas Núm 152 Colonia San Bartolo Atepehuacan, \\ Delegación Gustavo A. Madero, 07730 México, DF, Mexico
}

Correspondence should be addressed to E. Vega; evega@imp.mx

Received 4 September 2012; Revised 22 November 2012; Accepted 6 December 2012

Academic Editor: Ernesto Alfaro-Moreno

Copyright (C) 2013 G. Sosa et al. This is an open access article distributed under the Creative Commons Attribution License, which permits unrestricted use, distribution, and reproduction in any medium, provided the original work is properly cited.

Pollutant emissions and their contribution to local and regional air quality at the industrial area of Tula were studied during a fourweek period as part of the MILAGRO initiative. A recurrent shallow stable layer was observed in the morning favoring air pollutants accumulation in the lower $100 \mathrm{~m}$ atmospheric layer. In the afternoon the mixing layer height reached $3000 \mathrm{~m}$, along with a featuring low level jet which was responsible of transporting air pollutants at regional scales. Average $\mathrm{PM}_{10}$ at Jasso (JAS) and Tepeji (TEP) was 75.1 and $36.8 \mu \mathrm{g} / \mathrm{m}^{3}$, respectively while average $\mathrm{PM}_{2.5}$ was 31.0 and $25.7 \mu \mathrm{g} / \mathrm{m}^{3}$. JAS was highly impacted by local limestone dust, while TEP was a receptor of major sources of combustion emissions with $70 \%$ of the $\mathrm{PM}_{10}$ constituted by $\mathrm{PM}_{25}$. Average hourly aerosol light absorption was $22 \mathrm{Mm}^{-1}$, while aerosol scattering $\left(76 \mathrm{Mm}^{-1}\right)$ was higher compared to a rural site but much lower than at Mexico City. $\delta^{13} \mathrm{C}$ values in the epiphyte Tillandsia recurvata show that the emission plume directly affects the SW sector of Mezquital Valley and is then constrained by a mountain range preventing its dispersion. Air pollutants may exacerbate acute and chronic adverse health effects in this region.

\section{Introduction}

Recent research initiatives in Mexico have focused on the measurement of air pollutants, with particular emphasis on ozone and suspended particles, with the objective of establishing pollution controls on most industries. Major studies in central Mexico include the Mexico City Air Quality Research Initiative (MARI) in 1990 [1], the Investigacion sobre Materia Particulada y Deterioro Atmosferico-Aerosol and Visibility Evaluation Research (IMADA-AVER) in 1997 [2], the MCMA-2003 [3, 4], and the Megacity Initiative: Local and Global Research Observations (MILAGRO) in 2006. As part of the MILAGRO project, atmospheric pollutant concentrations and chemical composition were measured intensively in Tula (in the State of Hidalgo) during four weeks to determine the potential impact of contaminant emissions of Tula on the northern sector of Mexico City.

Mezquital Valley, localized some $60 \mathrm{~km}$ northwest of Mexico City Metropolitan Area (MCMA), is site of the Tula-Vito-Apasco industrial corridor where intensive anthropogenic activity, including oil refining, electrical generation, limestone extraction, and cement, textile and chemical production take place. In this site, both the biggest refinery in Mexico and the adjacent thermoelectric power plant use fuel oil, and it has been estimated that together they contribute with over $90 \%$ of the pollution in the valley $[5,6]$. Characterization of suspended particles in the area has shown an important contribution of soil fugitive dust by agricultural activity and limestone mincing; and particle emissions from the refinery and thermoelectric power plant complex (RTPPC) covering a considerable area regardless of wind direction [6]. Additionally, the cement industry contributes with particle emissions during material extraction in open pit mines, mincing, transportation, and high temperature incineration. The SE and NE sectors of the valley are used for agriculture, most of which is irrigated with residual waters from MCMA via the Tula River. Overall, the valley is site of considerable soil, water, and air pollution.

Several lines of evidence have associated air pollution with health effects. A direct correlation between particulate matter (PM) concentration and cardiovascular and respiratory diseases have been demonstrated $[7,8]$. Recent studies 
have shown positive association of PM chemical composition and mortality $[9,10]$. Epidemiological and toxicological studies found that the cytokine secretion patterns are influenced by the size and chemical composition of PM in Mexico City $[11,12]$. A recent study evaluated the association between PM and cases of mortality, acute respiratory infections, and asthma in the Tula-Tepeji region [13].

The high emissions, complex topography, wind circulation, and its closeness to MCMA have prompted the monitoring and modeling of plume dispersion from the Miguel Hidalgo Oil Refinery and the Francisco Perez Rios Power Plant and their effects on the northern sector of the MCMA. In particular, it has been estimated that nearly $50 \%$ of the $\mathrm{SO}_{2}$ concentrations in MILAGRO Supersite T1 (NE Mexico City) are attributable to these two industries $[5,14,15]$. A similar influence of other contaminants would thus be expected.

This paper documents a four-week daily data set on the concentrations of $\mathrm{PM}_{2.5}, \mathrm{PM}_{10}$, submicrometric particles, black carbon, light scattering, and criteria contaminants in addition to meteorological variables to further support the characterization of Tula emissions as a potential source of pollutants to Mexico City and nearby cities (Tepeji and Jasso). In addition, stable carbon isotopes in the epiphyte Tillandsia recurvata collected in Mezquital Valley during the study are used here as a proxy of the long-term trajectory of the emission plume.

\section{Study Area and Experimental}

2.1. Sampling Sites and Measurements. The Miguel Hidalgo refinery is the second largest refinery in Mexico, processing $3 \times 10^{5}$ barrels of crude oil per day, and it supplies the $50 \times 10^{6}$ liters per day of gasoline-equivalent (all fuels included) to Mexico City [16]. In turn, the Francisco Pérez Ríos power plant has $1.5 \mathrm{GW}$ of capacity and it mainly supplies the electricity demand for Central Mexico. The power plant has four major units fueled primarily by fuel oil (4\% sulfur by weight) and five small combined cycle units burning natural gas. In comparison, urban emissions due to transport and service/commerce activities in nearby localities (Tula de Allende, Atotonilco, Atitalaquia and Tepeji) represent a small contribution to local air pollution [17].

Three sampling sites within the Tula-Vito-Apasco corridor were selected to measure PM, and upper and surface meteorological parameters (Table 1).

2.1.1. Tula (TUL) Upper Air Monitoring Station. Tula (TUL) located inside the Instituto Mexicano del Petróleo facilities adjacent to the refinery $\left(99.27^{\circ} \mathrm{W}, 20.05^{\circ} \mathrm{N}\right)$. This site was selected as an upper air monitoring station to determine the diurnal evolution of the mixing height $(\mathrm{MH})$ as well as other meteorological variables, such as wind direction (WD) and wind speed (WS). These variables are essential in air quality studies to determine the vertical extension in which pollutants are mixed, dispersed, and transported [18].

A Vaisala radiosonde system (Model SPS-220) was used for upper air sounding measurements of pressure, temperature, relative humidity, and the horizontal wind vector, at different altitudes. Vertical profiles were determined
TABLE 1: Equipment deployed at each site and frequency of measurements.

\begin{tabular}{lcc}
\hline Equipment & Site & Frequency \\
\hline Rawinsondes & TUL & $8,12,15,18 \mathrm{~h}$ \\
Surface meteorology & TUL, JAS, TEP & $6 \mathrm{~min}$ \\
Minivols $\left(\mathrm{PM}_{2.5}, \mathrm{PM}_{10}\right)$ & JAS, TEP & $24 \mathrm{hrs}$ \\
Denuders & JAS, TEP & $24 \mathrm{hrs}$ \\
SMPS + DMA & JAS & $15 \mathrm{~min}$ \\
Nephelometer & JAS & $1 \mathrm{~min}$ \\
Aethalometer & JAS & $1 \mathrm{~min}$ \\
Criteria pollutants & JAS & $1 \mathrm{~min}$ \\
$\left(\mathrm{CO}, \mathrm{O}_{3}, \mathrm{NO}_{2}, \mathrm{SO}_{2}\right)$ & TEP & Continuous \\
MiniDOAS & Mobile & $1 \mathrm{hr}$ from 10 to $18 \mathrm{~h}$ \\
Pilot balloons & TUL
\end{tabular}

SMPS: scanning mobility particle sizer; DMA: differential mobility analyzer.

by launching four rawinsondes everyday at 08:00, 12:00, 15:00, and 18:00 h CST. Additionally, surface meteorological parameters, temperature $(T)$, ambient pressure $(P)$, relative humidity (RH), wind direction (WD), wind speed (WS), and solar radiation (SR) were also measured using a regular meteorological station. These measurements took place from 18 March to 17 April, 2006.

2.1.2. Jasso (JAS) and Tepeji (TEP) Surface Stations. JAS and TEP were considered as core sites where several equipments were installed to simultaneously measure criteria pollutants $\left(\mathrm{CO}, \mathrm{NO}_{2}, \mathrm{O}_{3}\right.$, and $\left.\mathrm{SO}_{2}\right), \mathrm{PM}$, and submicrometric particles. These sites are influenced by both urban and major industrial sources. JAS $\left(99.31^{\circ} \mathrm{W}, 20.02^{\circ} \mathrm{N}\right)$ is located about $5 \mathrm{~km} \mathrm{SW}$ from the refinery and the power plant, whereas major urban intercounty heavy traffic roads are located south and west. This site is close to a major limestone area where mining for cement materials occurs. TEP $\left(99.29^{\circ} \mathrm{W}, 19.86^{\circ} \mathrm{N}\right)$ is located $21 \mathrm{~km} \mathrm{~S}$ away from the refinery, far from urban areas but close to a major highway. This site is also close to the major cement plant and near limestone mining areas.

2.2. Meteorology and Criteria Pollutants. Surface meteorological parameters and criteria pollutants were measured from 22 March to 21 April 2006 at TEP, and from 25 March to 22 April at JAS. Measured variables included temperature, pressure, relative humidity, wind speed and wind direction, and $\mathrm{SR}(T, P, \mathrm{RH}, \mathrm{WS}, \mathrm{WD}$, and solar radiation, resp.). Criteria pollutants were measured using a mobile laboratory equipped with conventional analyzers (Monitor Labs). Methods used to determine criteria pollutants were NOM-034SEMARNAT-1993 using dispersive spectroscopy for CO, NOM-037-SEMARNAT-1993 using chemoluminescence for $\mathrm{NO}_{x}$, USEPA-EQOA-0193-091 using UV photometry for $\mathrm{O}_{3}$, and USEPA-EQSA-0193-092 using pulse fluorescence for $\mathrm{SO}_{2}$.

2.3. Particulate Matter (PM). PM samples were collected daily from $00: 00$ to $24: 00 \mathrm{~h}$ using portable low volume MiniVol samplers (Airmetrics, Springfield, USA) at a flow 


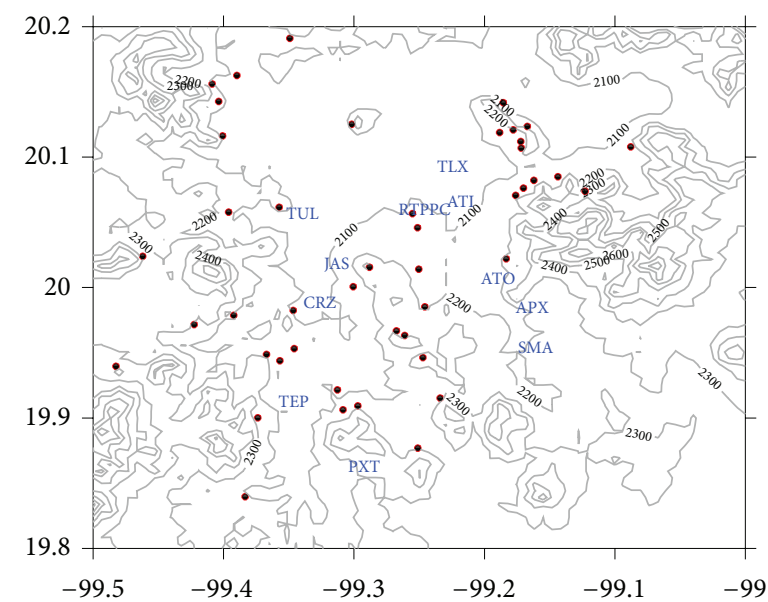

(a)

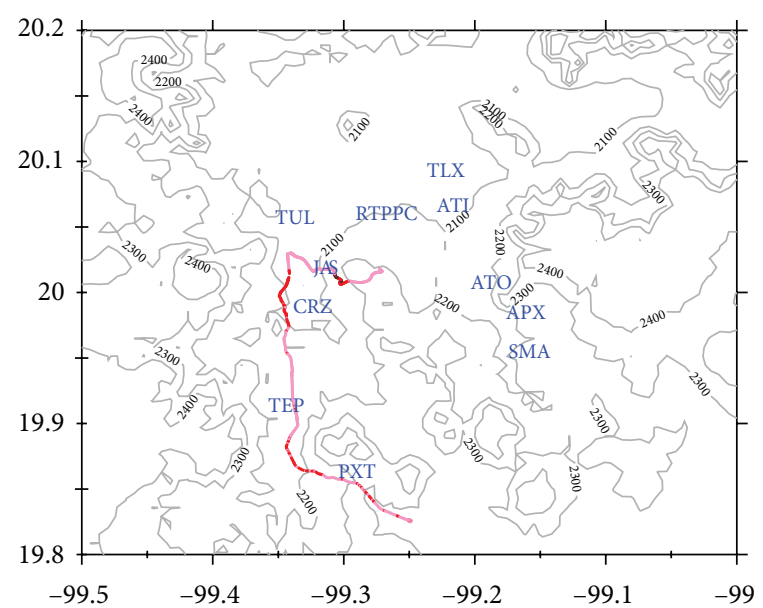

(b)

FIGURE 1: (a) Mezquital Valley topography with sampling sites (circles), major population centers, and the refinery-thermoelectrical plant complex. (b) Trajectory of the $\mathrm{SO}_{2}$ dispersion plume in SE direction observed on April 4, 2006 at 16:00 and 17:00 hours. APX: Apaxco, ATO: Atoyac, ATI: Atitalaquia, CRZ: Cruz Azul, JAS: Jasso; PXT: PEMEX gas substation; RTPPC: refinery thermoelectrical power plant complex; SMA: Santa María Apaxco; TEP: Tepeji; TLX: Tlaxcoapan; TUL: Tula.

rate of $5 \mathrm{~L} / \mathrm{min}$, previously calibrated at standard conditions. In addition sequential filter samplers (SFS) equipped with $\mathrm{PM}_{2.5}$ (Bendix 240 cyclones) and $\mathrm{PM}_{10}$ (Andersen SA254) samplers operated at a flow rate of $113 \mathrm{~L} / \mathrm{min}$ were used to collect 12-hour samples (06:00 to 18:00 and from 18:00 to 06:00). Samples were collected on $47 \mathrm{~mm}$ Teflon-membrane (Pall Gelman Laboratory, Ann Arbor, MI, USA) and quartzfiber filters (Pallflex Gelman Sciences CT, USA). Teflon filters were used for mass, trace element analyses, and for light transmission, whereas quartz filters were used for ion and elemental and organic carbon analyses [19].

2.4. Submicrometric Particles and Optical Properties. Light scattering coefficients were measured with an integrating nephelometer (Model 3563 TSI, Inc.) operating at 450, 550, and $700 \mathrm{~nm}$. Submicrometric particle surface distribution was obtained with a scanning mobility particle sizer (SMPS) (Model 3936 TSI, Inc.). Black carbon mass concentrations were measured with an aethalometer (Model AE-16 Magee Scientific, Co) operating at $880 \mathrm{~nm}$.

2.5. Stable Carbon Isotopes. Long-term atmospheric deposition patterns for selected trace metals, PAHs, and stable carbon isotopes covering an area of $4000 \mathrm{~km}^{2}$ were determined with samples of ball-moss (Tillandsia recurvata) at 50 sites as atmospheric biomonitors. These patterns reflect the long-term air pollutant transport from the oil industry and other economic activities in Mezquital Valley according to the prevailing winds. This moss satisfies basic attributes of a biomonitoring organism, such as its widespread occurrence in the valley, and its dependence on atmospheric nutrients and humidity $[20,21]$. Therefore metal, PAHs, and stable carbon isotope composition in this species serve as proxies of atmospheric emissions impact at different distances from the emission source. In this paper, stable carbon isotopes in
T. recurvata were used as a tracer of long-term signature of the plume trajectory. Metals, stable isotopes, and PAHs in T. recurvata are described by Zambrano García et al. [22] to show the signature source of the principal emitters in Mezquital Valley.

Total flux emissions and tracking of the $\mathrm{SO}_{2}$ plume were determined at major sources in the region to identify transport pathways towards Mexico City under different meteorological conditions using a mobile Differential Optical Absorption Spectroscopy (MiniDOAS) system. Details of the technique and results are described by Rivera et al. [5].

Figure 1 shows the sites where $T$. recurvata were sampled in the vicinity of the refinery and thermoelectric power plant complex (RTPPC), which is located nearby several small towns, at an altitude of around $2100 \mathrm{~m}$ above sea level. Note the mountain chain to the E-SE of the RTPPC which rises approximately $400 \mathrm{~m}$ above the valley. Winds measured in March to April, 2006 [22], and October to December, 2008 [23] in the region show highest speeds when coming from the $\mathrm{NE}$ and SW quadrants. Figure shows the $\mathrm{SO}_{2}$ concentrations measured along the miniDOAS path.

\section{Results and Discussion}

\subsection{Meteorology}

3.1.1. Synoptic Overview. Field measurements and largescale analysis showed that local meteorological conditions and air pollutants transport were affected by the synoptic systems development. Detailed descriptions on meteorological conditions during the MILAGRO campaign are reported by Fast et al. [24]. Three major synoptic-scale systems were observed during the field campaign. The more frequent events were high-pressure systems, remaining quasistationary at central Mexico, followed by troughs and rides 


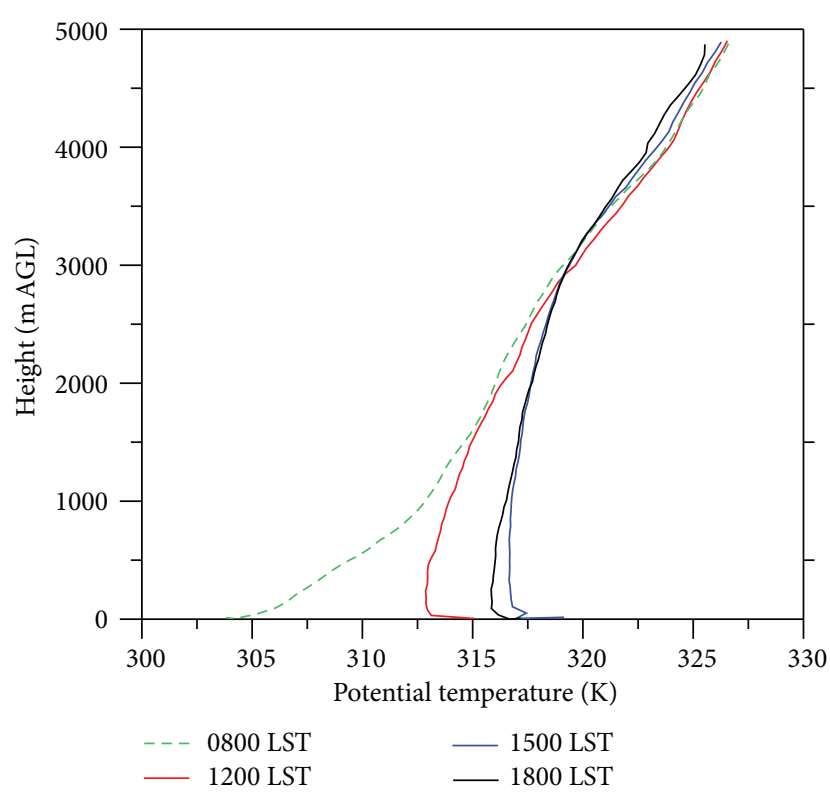

(a)

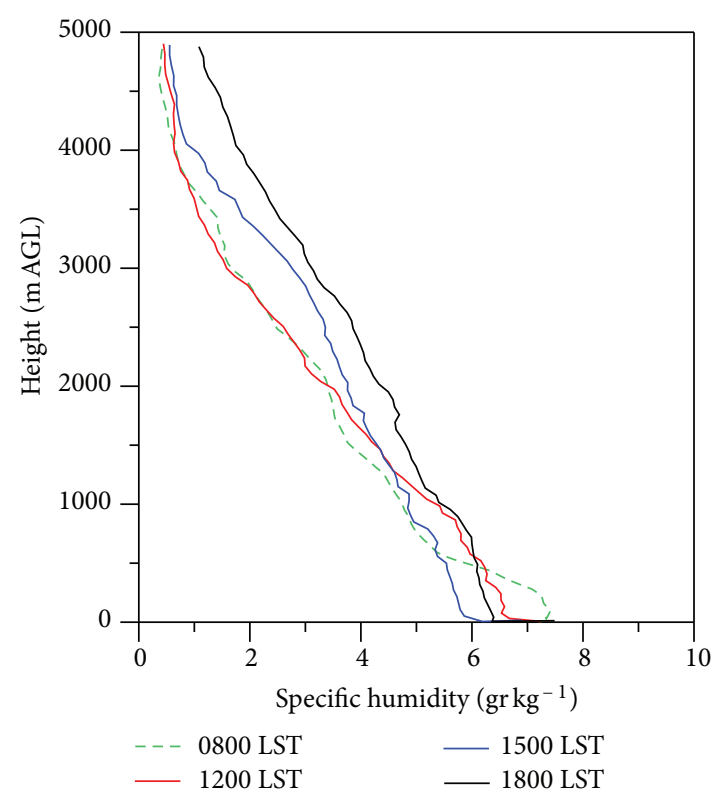

(b)

FIGURE 2: Mean potential temperature (a) and specific humidity profiles (b) at Tula.

passages at south-central U. S. Cold surges. The third and least frequent system was cold surges (northern) influencing mainly the coast line at Gulf of Mexico and was also present during the study period. Both during early March and on March 18-19, upper-level troughs propagated through southcentral U. S. producing strong southwesterly winds in the central plateau. Two cold surges were observed on March 22 and 24-26 causing strong northerly near-surface flow over the Gulf of Mexico. High-pressure systems predominated during the remaining sampling days, and were typical characterized by clear skies, low humidity, and weak winds.

Winds below the mixing layer at $700 \mathrm{hPa}(1000 \mathrm{~m}$ above ground level) were variable according to the dominant synoptic system in the region. Westerly and southwesterly winds were associated to a trough pass; northerly and easterly winds to high-pressure systems slowly moving from northwestern Mexico towards the east, and strong northerly nearsurface flows over de Gulf of Mexico were associated to cold surges. The frequency of upper wind direction at $500 \mathrm{hPa}$ measured at $06: 00 \mathrm{~h}$ were $45.2 \%$ southwesterly, $35 \%$ westerly, $13 \%$ northeasterly, and $3.2 \%$ corresponding to south and northwesterly winds. Daily maximum surface temperature was over $22^{\circ} \mathrm{C}$ most of the days; however, during the period of March 24-26, during a cold surge passage, temperature dropped to $18^{\circ} \mathrm{C}$. Surface wind speeds, varying from light to moderate, were observed throughout the study.

3.1.2. Height of the Boundary Layer. Figure 2 shows the mean potential temperature and specific humidity profiles for the field campaign. The profiles were obtained averaging all radiosonde data available at each launch time. During most of the sampling period ( $80 \%$ of the time), a stable layer was observed at 08:00 h, with the occasional presence of near-surface thermal inversions; by noon, when solar heating breaks the stable layer, a well-developed mixing layer reached up to $2000 \mathrm{~m}$ above ground level (AGL), with a shallow superadiabatic layer near the surface. Although potential temperature profiles were similar above $500 \mathrm{~m}$ at 15:00 and $18: 00 \mathrm{~h}$, the colder temperatures at $18: 00 \mathrm{~h}$, indicated the formation of a stable layer close to the surface (Figure 2(a)). Specific humidity profiles showed a reduction of water content with height, and a well-mixed atmosphere after the breakup of the stable layer. The difference on the water vapor content among vertical profiles was less than $4.0 \mathrm{~g} / \mathrm{Kg}$ throughout the study (Figure 2(b)).

Data analysis of the radiosonde data showed that the mixing layer height (ML) varied significantly from 2500 to $4200 \mathrm{~m} \mathrm{AGL}$, reaching its average diurnal maximum at 15:00 h. When a strong cold surge entered Central Mexico during March 24-25, the ML decreased to less than $500 \mathrm{~m}$ $\mathrm{AGL}$, due to a reduction in the solar radiation as a consequence of cloudy skies and scattered rain.

3.1.3. Mean Wind Profiles at the Boundary Layer. Figure 3 gives the mean wind profiles calculated from rawinsondes data during the field campaign at 08:00, 12:00, 15:00, and 18:00 hs. The horizontal lines represent variations with height of the wind persistence, defined as the ratio of the vectorial mean wind speed to scalar wind speed. Ratios close to one indicate almost no change in wind direction; on the contrary, values close to zero indicate a large variation in wind direction.

Figure 3(a) shows a highly variable and stratified atmosphere at 08:00 h. The change in wind persistence with height varied from less than 0.2 to greater than 0.6 , being more stable at heights lower than $100 \mathrm{~m} \mathrm{AGL}$ and above $5000 \mathrm{~m}$ 


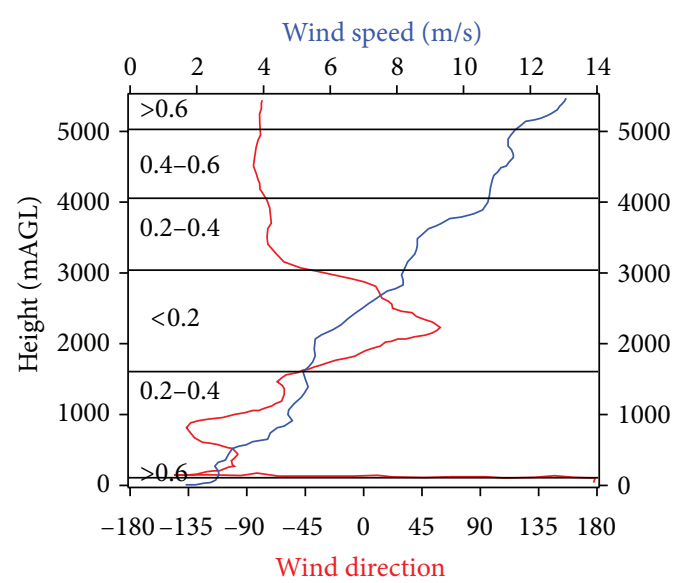

(a)

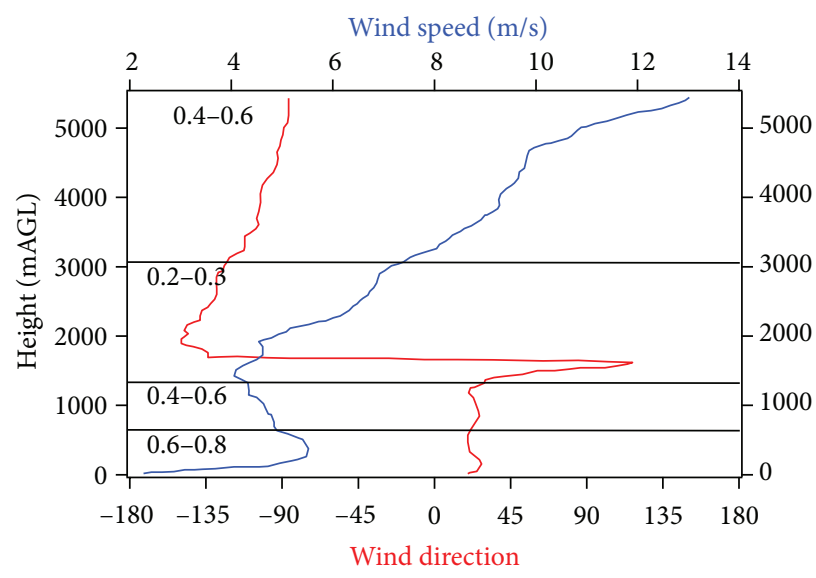

(c)

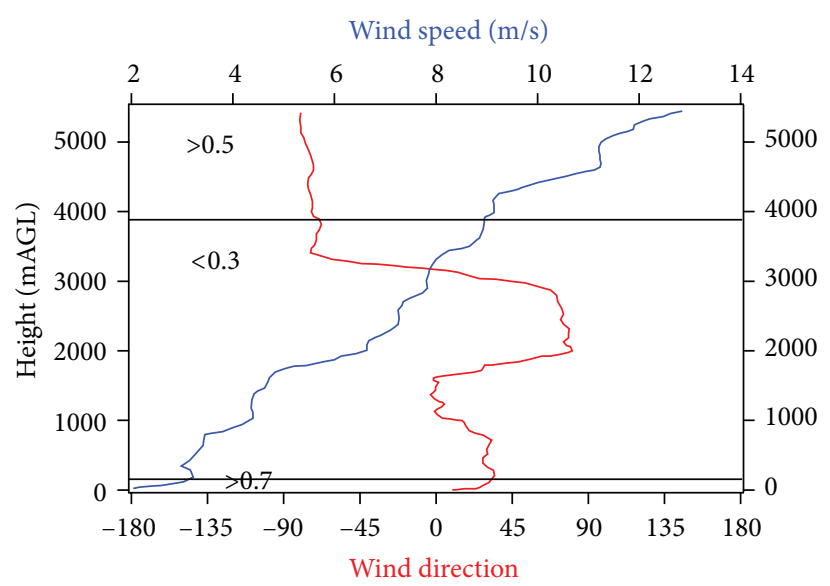

(b)

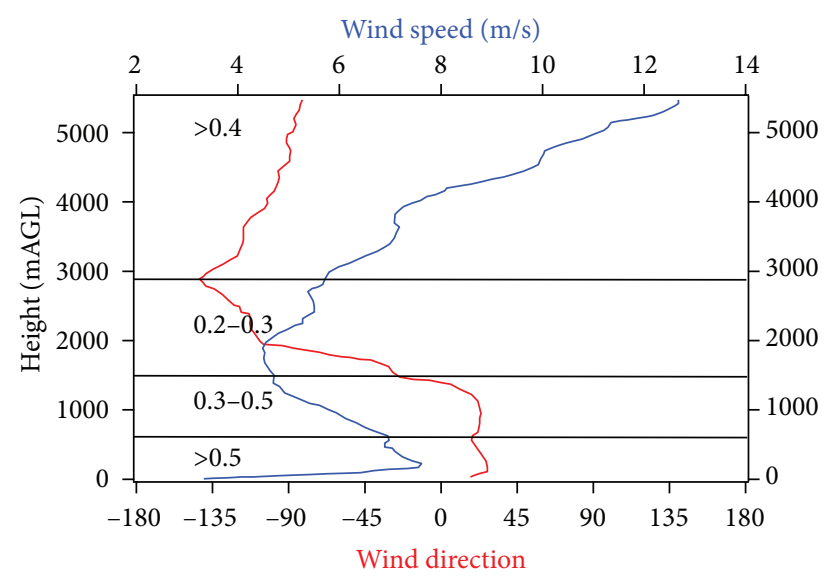

(d)

Figure 3: Mean wind profiles at Tula, during March-April, 2006. Horizontal lines represent the wind persistence value.

AGL. Near-surface southerly to southwesterly winds were observed regularly along the field campaign. At 12:00 h, a less stratified atmosphere was observed, although a varying wind speed layer, from $300 \mathrm{~m}$ to $4000 \mathrm{~m}$ AGL, still remained (Figure 3(b)). Below 1500 m AGL, northeasterly wind speed was more stable; however, wind speed increased constantly and therefore the wind persistence was low, reflecting the ML evolution into a well-mixed layer. At 15:00 h, the wind persistence ratio ranged from 0.2 to 0.86 under the lowest 5000 meters of the troposphere, although a clearly more homogeneous mixing layer was observed (Figure 3(c)). Below $1500 \mathrm{~m}$, the mean northeasterly wind remained constant, and the wind speed profile shows a northeasterly jet near the surface, with a maximum value close to $6 \mathrm{~m} / \mathrm{s}$ at $500 \mathrm{~m}$ AGL. Figure $3(\mathrm{~d})$ shows the mean wind profile at 18:00 h, which is similar to the wind profile at 15:00 h, but with more variability in wind direction and with a stronger jet closer to the ground (at $250 \mathrm{~m}$ and maximum velocity of $7 \mathrm{~m} / \mathrm{s}$ ).

In summary, early in the morning $(8: 00 \mathrm{~h})$, a shallow stable layer formed near the surface, with light southsouthwesterly winds. These conditions favored the accumulation of air pollutants below $100 \mathrm{~m}$ with a limited dispersion towards the north Tula industrial complex. After midday, a well-developed mixing layer favored the mixing of pollutants at higher altitudes (up to $5000 \mathrm{~m}$ AGL). Simultaneously, a near-surface superadiabatic layer, with a clear northern wind component, brought back the previously-advected pollutants. In the afternoon and evening a thicker mixing layer reached on average 2500 to $3000 \mathrm{~m}$ height, featuring a weak low level jet (LLJ) near the surface. This LLJ was responsible of transporting air pollutants at regional scales. According to the authors' knowledge, this is the first time this feature is reported for the region.

LLJ can develop under favorable synoptic conditions anywhere in the world. This pattern is characterized by space scales between 20 and $200 \mathrm{~km}$ within the lowest $2000 \mathrm{~m}$ of the atmosphere, where strong diurnal oscillations and nocturnal accelerations occur [25]. The development of LLJ is associated with nocturnal temperature inversion, forming in the late afternoon or early evening and becoming strongest during the early morning hours of the next day, and then weakening or disappearing by late morning. From Figures 2(a), 3(c), and 3(d), it is clear that temperature and wind profiles fulfill these requirements. Although no early-morning sounding was available to corroborate that, maximum wind speed occurred at this time. 
TABle 2: Average, maximum, and minimum of $24 \mathrm{~h}$ and $12 \mathrm{~h}$ of $\mathrm{PM}_{10}$ and $\mathrm{PM}_{2.5}$ during the sampling period of March 24-20 April, 2006.

\begin{tabular}{|c|c|c|c|c|c|c|}
\hline & \multicolumn{3}{|c|}{ Jasso } & \multicolumn{3}{|c|}{ Tepeji } \\
\hline & Average & Maximum & Minimum & Average & Maximum & Minimum \\
\hline $\mathrm{PM}_{2.5} 24 \mathrm{~h}$ & 31.0 & 52.0 & 14.3 & 25.7 & 53.1 & 14.5 \\
\hline $\mathrm{PM}_{2.5}$ 06:00-18:00 & 45.5 & 70.3 & 18.2 & 35.5 & 75.1 & 16.8 \\
\hline $\mathrm{PM}_{2.5} 18: 00-06: 00$ & 31.0 & 59.2 & 10.3 & 24.9 & 37.6 & 12.0 \\
\hline $\mathrm{PM}_{10} 24 \mathrm{~h}$ & 75.1 & 178.6 & 30.4 & 36.8 & 53.2 & 22.4 \\
\hline
\end{tabular}

Implications of these meteorological conditions on human health are evident. First, the persistent stable atmospheric conditions in the morning favor the concentration of pollutants near ground, increasing the level of exposure of the inhabitants. This condition may worsen at winter time, when lowest temperatures drop below $0^{\circ} \mathrm{C}$. On the other hand, the regional transport of pollutants increases the number of people exposed to these air pollutants. These results are in agreement with those recently reported by Almanza et al. [15]. By using dispersion models, the authors estimated the fraction of time at which the RTPPC plume hits the surface in the full domain. Regardless the concentration at which the plume reaches the ground, the impact on the Mexico MCMA may be $40 \%$ to $60 \%$ of the time [15].

3.2. Criteria Pollutants. Air quality standards (AQS) at JAS such as ozone $(0.11 \mathrm{ppm}$, average of $1 \mathrm{~h})$, carbon monoxide (11 ppm mobile average of $8 \mathrm{~h})$, sulfur dioxide $(0.13 \mathrm{ppm}$ average of $24 \mathrm{~h})$, and nitrogen dioxide $(0.210 \mathrm{ppm}$, average of $1 \mathrm{~h}$ ) were not exceeded [26]. Maximum hourly values were $0.034,0.033$, and $0.287 \mathrm{ppm}$ for $\mathrm{O}_{3}, \mathrm{NO}_{2}$, and $\mathrm{CO}$, respectively. The maximum average of $24 \mathrm{~h}$ for $\mathrm{SO}_{2}$ was $0.0078 \mathrm{ppm}$, on April 5, even though this pollutant increased to $0.293 \mathrm{ppm}$ at midday on April 14 .

The results at TEP showed that $\mathrm{CO}$ and $\mathrm{NO}_{2}$ concentrations were below their corresponding AQS values. However, the $\mathrm{SO}_{2}$ exceeded the standard twice, on March 26 with 0.185 ppm, and April 14 with 0.190 ppm. $\mathrm{O}_{3}$ also exceeded the standard during the April 27 with $0.122 \mathrm{ppm}$. In general, this site showed higher concentrations of $\mathrm{SO}_{2}$ when compared to JAS, with maximum hourly values between 0.100 and 0.300 ppm.

Most of the $\mathrm{SO}_{2}$ is released from the refinery and the RTPPC facilities at a height of $60 \mathrm{~m}$ above ground level, although the effective height of the emissions may rise above $1000 \mathrm{~m}$, due to buoyancy provided by hot exhaust. Under these conditions, the emission plume travels long distances downwind before reaching the ground, which is in agreement with mini-DOAS measurements reported by Rivera et al. [5]. Sites located nearby the source are below the plume and thus report lower $\mathrm{SO}_{2}$ concentrations when compared to those farther from the plume source (Figure 1(b)).

3.3. Particulate Matter (PM). Table 2 summarizes the PM10 $24 \mathrm{~h}$ average concentrations during the sampling period for March 24-April 20, 2006. Also the $24 \mathrm{~h}$ average $\mathrm{PM}_{2.5}$ concentrations during March 24-April 6, 2006 and $12 \mathrm{~h}$ average $\mathrm{PM}_{2.5}$ concentrations during April 7-20, 2006 were given at standard conditions. In general, PM concentrations measured at the JAS urban-industrial site were higher than at TEP, which may indicate the magnitude of local limestone dust resuspension from quarrying. Particle contribution at this site is exacerbated by the cement industry which is also a heavy user of residual fuel oil, petroleum coke, and an assortment of industrial wastes.

PM mass concentrations oscillated substantially from day to day at both sites. The most extreme variations occurred at JAS in the $\mathrm{PM}_{10}$ fraction and $\mathrm{PM}_{10}$ levels at JAS showed considerably variations from 30.4 to $178.6 \mu \mathrm{g} / \mathrm{m}^{3}$ with an average of $75.1 \mu \mathrm{g} / \mathrm{m}^{3}$; the $24 \mathrm{~h}$ average of $120 \mu \mathrm{g} / \mathrm{m}^{3}$ [27] was exceed twice during the study. While $\mathrm{PM}_{2.5}$ ranged between 14.3 to $52.0 \mu \mathrm{g} / \mathrm{m}^{3}$ with an average of $31.0 \mu \mathrm{g} / \mathrm{m}^{3}$, the $\mathrm{PM}_{2.5}$ standard of $65 \mu \mathrm{m} / \mathrm{m}^{3}$ was not exceeded during the sampling campaign. High $\mathrm{PM}_{10}$ concentrations were observed on April 8 and 11 with values of 162.2 and $178.6 \mu \mathrm{g} / \mathrm{m}^{3}$, respectively. Those two days had light wind speed in the morning $(<1.56 \mathrm{~m} / \mathrm{s})$ with variable wind direction. After 10:00 h, southwest winds became more stable and increased their speeds to a maximum of $8.0 \mathrm{~m} / \mathrm{s}$ at $18: 00 \mathrm{~h}$. On these days, the corresponding $\mathrm{PM}_{2.5}$ mass concentrations (49.5 and $36.7 \mu \mathrm{g} / \mathrm{m}^{3}$, resp.) were less than one-third of the $\mathrm{PM}_{10}$, which is less than the $\mathrm{PM}_{2.5} / \mathrm{PM}_{10}$ average ratio of 0.41 , and suggests that elevated $\mathrm{PM}_{10}$ concentrations can be attributed to local fugitive dust. Similar temporal variations of $\mathrm{PM}_{2.5}$ mass concentrations were observed from March 26 to April 3 with a smooth increase from and with two peaks on the same dates as PM10. Similar PM10 levels were reported by Querol et al. [28] in the urban area of Mexico City with 24-hour averages ranging between 50 and $56 \mu \mathrm{g} / \mathrm{m}^{3}$, and $\mathrm{PM}_{2.5}$ between 24 and $40 \mu \mathrm{g} / \mathrm{m}^{3}$; however, these values were measured during March as a part of the MILAGRO campaign and cannot be compared directly with our observations.

At TEP $\mathrm{PM}_{10}$ concentrations were higher during a longer period of time (April 5-13). In general, during April winds were light $(2 \mathrm{~m} / \mathrm{s})$ and variable in average, although maximum daily speeds ranged from 7 to $9 \mathrm{~m} / \mathrm{s}$. During April 5-13, higher wind speeds were recorded compared to the period of April 14 to 19, where lower PM concentrations were observed, due to more stable wind conditions. Wind directions were variable before 8:00 h, were persistent from southeast until noon, and changed direction from northeast in the evening. $\mathrm{PM}_{10}$ concentrations at TEP ranged from 22.4 to $53.2 \mu \mathrm{g} / \mathrm{m}^{3}$ with an average of $36.8 \mu \mathrm{g} / \mathrm{m}^{3}$, while $\mathrm{PM}_{2.5}$ varied between 14.5 to $53.1 \mu \mathrm{g} / \mathrm{m}^{3}$ with an average of $25.7 \mu \mathrm{g} / \mathrm{m}^{3}$. Although the fine fraction at both sites were 
similar, the difference was driven by the $\mathrm{PM}_{10}$ fraction as the $\mathrm{PM}_{2.5} / \mathrm{PM}_{10}$ mass ratio ranged from 0.85 to 0.50 with an average of 0.68 indicating that this site is a receptor of the industrial emissions from the major sources of combustion processes.

The $\mathrm{PM}_{2.5} / \mathrm{PM}_{10}$ ratio at JAS is similar to those reported by Vega et al. [19] for Mexico City (0.46), and for the industrialized area of Salamanca (0.33) in Guanajuato [29], where the contribution of fugitive dust is considerable.

$\mathrm{PM}_{2.5}$ was consistently higher during the morning periods (06:00-18:00h), with average values of 35.5 and $45.5 \mu \mathrm{g} / \mathrm{m}^{3}$, and decreased during the night (18:00-06:00 h) to 24.9 and $31.0 \mu \mathrm{g} / \mathrm{m}^{3}$ at TEP and JAS, respectively. This is consistent with a recurrent shallow stable layer formed near the surface before 8:00 $\mathrm{h}$ and light winds favoring particle accumulation. At TEP maximum concentrations of 75.1 and $37.6 \mu \mathrm{g} / \mathrm{m}^{3}$ occurred in April 11 and 16 for morning and night, respectively. In contrast, JAS maximum concentrations were measured in the morning of April $8\left(70.3 \mu \mathrm{g} / \mathrm{m}^{3}\right)$ and at night on April $7\left(59.2 \mu \mathrm{g} / \mathrm{m}^{3}\right)$.

The aforementioned pattern is in agreement with the continuous black carbon measurements which were influenced by fresh emissions from major industrial combustion sources (Figures 4 and 7). Similar patterns were also reported for Mexico City during the same period of sampling [28]. It should be mentioned that carbonaceous aerosols, specifically black carbon, are the major absorbing aerosol species which may have an important warming impact at a regional scale. The aethalometer used to measure black carbon takes into account the flow rate, time, and a factor for the multiple scattering enhanced mass absorption efficiency [30].

There was a significant difference between both sites in the coarse fraction $\left(\mathrm{PM}_{10}-\mathrm{PM}_{2.5}\right)$, JAS being the mostly impacted by particles resulting from local limestone dust from quarrying, as it ranged from 40 to $79 \%$ with an average of $56 \%$. At TEP this fraction varied from 15 to $50 \%$ with an average of $32 \%$,. These results are consistent with higher emission from fossil fuel combustion processes from the RTPPC), among other sources in the vicinity of TEP (21 km south from the sources). In turn, Querol et al. [28] reported $50 \%$ of coarse fraction at CENICA, similar to JAS, while the urban T0 site had a lower contribution of coarse fraction (30\%), similar to TEP.

The incidence of respiratory diseases is higher in Tula than in any other area within Hidalgo State. Specifically, the central area of Tula the incidence of acute respiratory infections is the highest within Mexico [31]. In addition, MelgarPaniagua et al. [13] reported that there is an association between PM concentration and the increase of respiratory morbidity and mortality in Tula. Furthermore, there is evidence that exposure to ambient PM chemical components, such as sulfate, metals, elemental, and organic carbon, is associated with adverse health outcomes [32,33].

Results from chemical analysis, which will be presented in a future publication, showed that at JAS the higher concentrations of $\mathrm{PM}_{10}$ were driven by Ca, whilst in Mexico City the higher $\mathrm{PM}_{10}$ concentrations were correlated with $\mathrm{Si}$ [19]. High Ca concentrations are mainly due to limestone mining

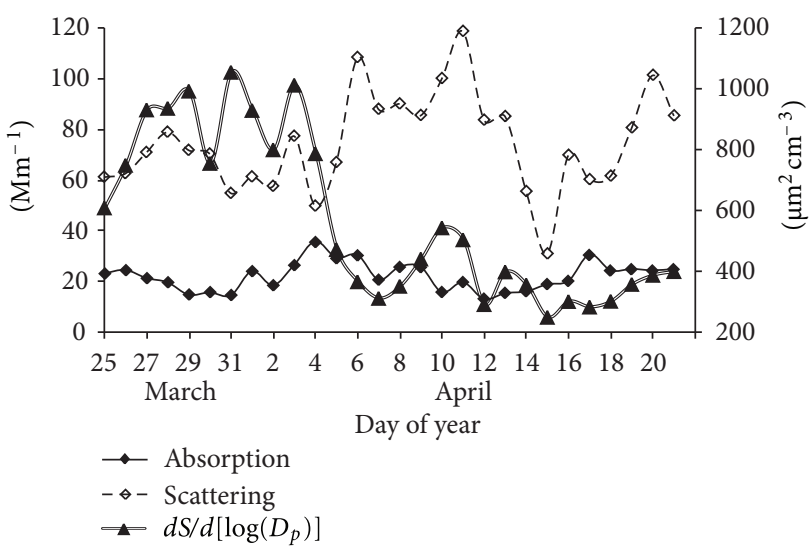

FIGURE 4: Daily aerosol light absorption and scattering obtained at $550 \mathrm{~nm}$, and submicrometric particles surface distribution, at JAS from March 25 to April 21, 2006.

for cement materials and limestone quarries nearby JAS and in the surroundings of Tula [22]. This contrasts with Siassociated $\mathrm{PM}_{10}$, which result from dust resuspension from the dry Texcoco Lake in Mexico City [19]. Higher Ca concentrations and in some cases also high $\mathrm{SO}_{4}{ }^{2}$ concentrations were also correlated with $\mathrm{PM}_{2.5}$. Sulfates showed a gradually increase at TEP starting on April 9 and showed a peak on April 12. The results of the radiosonde data analysis, below $1000 \mathrm{~m}$ which is the maximum mixing layer height during the day, confirm that on April 12, there were persistent winds all day coming from north and northeast with an average velocity ranging from 4 to $9 \mathrm{~m} / \mathrm{s}$ with direct influence from limestone quarries located upwind. On the other hand, $\mathrm{Ca}$ generally showed a similar pattern to $\mathrm{PM}_{10}$ mass with peaks driven by high Ca concentrations. On April 16, however, low $\mathrm{Ca}$ concentrations and high $\mathrm{PM}_{10}$ values were observed. A deeper mixing layer was developed on that day, reaching $3.5 \mathrm{~km}$. Winds were lighter and its direction changed early in the morning from south to west at noon, and then in the afternoon from north to east in the evening. This suggests that different emission sources contributed to high particle concentration, including those from agricultural activities, where $\mathrm{Si}$ is abundant.

3.4. Optical Properties. Light scattering, absorption, and surface size distribution represent different physical properties of particles and no direct comparison among them is always possible; however, all these parameters are a function of particle size and an analysis of its behavior can give an insight from the origin of particles.

3.4.1. Light Scattering. Figure 4 shows the daily light scattering distribution determined with a nephelometer at $550 \mathrm{~nm}$. In general, a large variability was observed along the sampling period with high light dispersion episodes observed on April 6-8 and April 11-13 when low mixing heights were observed. After April 15 the scattering values decreased to background values. Similar trends for 450 and $700 \mathrm{~nm}$ wavelengths were observed (not shown). This high dispersion associated with 


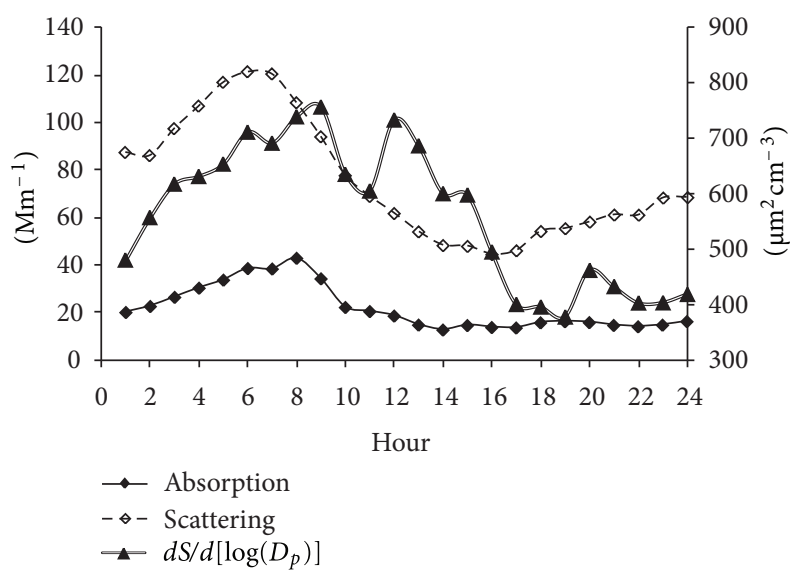

FIGURE 5: Hourly aerosol light absorption and scattering obtained at $550 \mathrm{~nm}$; submicrometric particles surface distribution at JAS from March 25 to April 21, 2006.

low mixing heights is consistent with pollutant concentration near the surface. In contrast, a decrease in light scattering, and thus a greater visibility occurred when mixing heights were greater.

Since Tula is classified as a "critical area" due to the high $\mathrm{SO}_{2}$ and $\mathrm{PM}$ emissions, it should also be expected to have high $\mathrm{SO}_{4}=$ concentration. Sulfate is an important light scattering aerosol species contributing to atmospheric cooling, formed from the atmospheric oxidation of $\mathrm{SO}_{2}$ [30].

The hourly aerosol scattering at JAS, at $550 \mathrm{~nm}$ ranged from $44-121 \mathrm{Mm}^{-1}$ with an average of $76 \mathrm{Mm}^{-1}$. When compared to the rural site of Tecamac $\left(53 \mathrm{Mm}^{-1}\right)$ located $29 \mathrm{Km}$ northeast of Mexico City, this value was higher by a factor of 1.4, but much lower than the urban area of Mexico City $\left(105 \mathrm{Mm}^{-1}\right)$ reported by Marley et al. [34] during March 10-29, 2006. Light scattering is clearly an important factor during the night and before 10:00 h, with a substantial reduction afterwards (Figure 5).

Higher scattering values, due to a persistent shallow stable atmospheric layer which traps most primary pollutants emitted below $500 \mathrm{~m}$ (Figure 2), were observed at night and before 10:00 in the morning, reaching a maximum at 7:00 with values as high as $121 \mathrm{Mm}^{-1}, 3.5$ hours earlier than the maximum scattering values seen at Mexico City [34] suggesting a rapid secondary aerosol formation. After 10:00 h, a decrease of scattering values was observed due to the development of the mixing layer favoring the dilution of air pollutants.

3.4.2. Submicrometric Particles. Figures 4-6 show the submicrometric particle surface size distribution $\left(\mathrm{dS} / \mathrm{d}\left[\log \left(D_{\mathrm{p}}\right)\right]\right)$, calculated by the SMPS system assuming spherical particles with diameters $\left(D_{\mathrm{p}}\right)$ from 15.7 to $764 \mathrm{~nm}$, measured at JAS from March 24 to April 21, 2006. In general, highest values were observed during March 26 to April 5 (Figure 4). The hourly highest values were observed between 6:00 and 9:00 h and after noontime (12:00 to 15:00 h) (Figure 5). Particles with diameters between 0.118 and $0.269 \mu \mathrm{m}$ contributed with $50 \%$ of the total particle surface size distribution. Particles

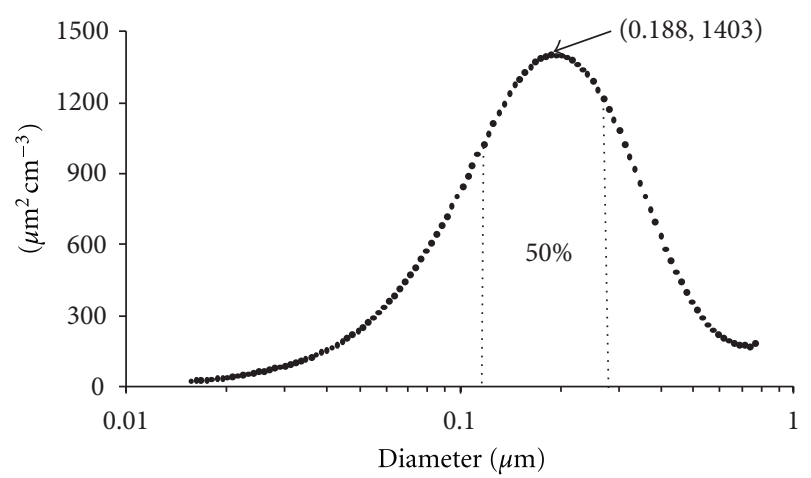

FIGURE 6: Submicrometric particles surface distribution by size, at JAS from March 25 to April 21, 2006.

smaller than $0.118 \mu \mathrm{m}$ and higher than $0.269 \mu \mathrm{m}$ contributed with $25 \%$ each (Figure 6). Implications of exposure to these particles on human health are presented by Buonanno et al. [35, 36], which studied average particle number size distribution data together with the people activity pattern to estimate the tracheobronchial and alveolar dose of submicrometer particles for different population age groups and under different exposure microenvironments in Italy.

3.4.3. Black Carbon. An absorption Angstrom exponent of 1 [34-38] was applied to the calculation of attenuation to determine its dependence with wavelength. Since almost all fresh emissions in this region come from the combustion of fossil fuel at the refinery and the power plant then the specific attenuation of $14625 / \lambda$ [37] was used to convert black carbon concentrations measured at $880 \mathrm{~nm}$ and be able to compare to results of aerosol absorption at $550 \mathrm{~nm}$ measured at the same period reported by Marley et al. [34].

Figure 7 shows that the highest concentration of BC from 2:00 to $11: 00 \mathrm{~h}$ is coincident with the reciprocal of wind speed (1/WS) peak. There is an increase of $10.3 \% / \mathrm{h}$ of BC concentrations from 1:00 to $8: 00 \mathrm{~h}$, and a decrease of $4.2 \% / \mathrm{h}$ of the $1 / \mathrm{WS}$, suggesting that fresh emissions have a major effect than the light wind speed ( 1.36 to $1.85 \mathrm{~ms}^{-1}$ ); furthermore, the boundary layer was stable favoring stagnation of pollutants. From 09:00 to 18:00 h, both BC and 1/WS decrease at a similar rate of 15 and $12 \% / h$, respectively. During this period the mixing layer is more important than either the fresh emissions or the wind speed. From 19:00 to 24:00 h, the air parcel stagnation increased $22 \% / \mathrm{h}$ meanwhile BC increased only $0.6 \% / \mathrm{h}$, so neither the fresh emissions nor the wind speed or the mixing layer were dominant for determining the levels of $\mathrm{BC}$.

Figures 4 and 5 show the daily and hourly aerosol light absorption measured at $880 \mathrm{~nm}$ and corrected to $550 \mathrm{~nm}$ at JAS from March 24 to April 21, 2006. In general, there was a continuous increase during the first hours of the day, from 01:00 to 08:00 $\mathrm{h}$, and then there was a decrease from 9:00 to $14: 00$ and from $15: 00$ to $24: 00 \mathrm{~h}$, there was an average absorption of $15 \mathrm{Mm}^{-1}$. On a daily basis, highest absorptions were observed during April 4-6 with up to $36 \mathrm{Mm}^{-1}$ (Figure 4) which correlates with an excess of liquid products flaring in 


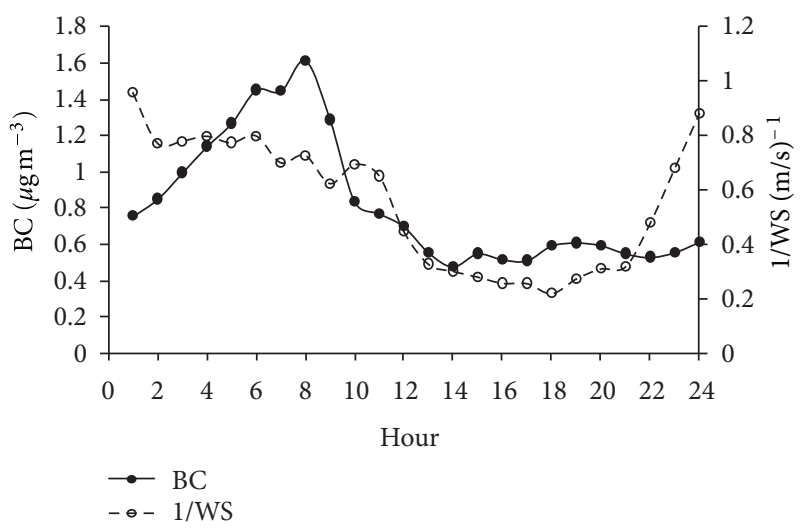

FIGURE 7: Hourly average black carbon (BC) concentration and reciprocal wind speed (1/WS).

the refinery due to a failure in a process that lasted two days. The highest absorption reached $43 \mathrm{Mm}^{-1}$ between 2:00 and 9:00 h (Figure 5). The hourly aerosol light absorption varied between 13-43 $\mathrm{Mm}^{-1}$ with an average of $22 \mathrm{Mm}^{-1}$ which is smaller compared to both values at Mexico City $\left(37 \mathrm{Mm}^{-1}\right)$ and Tecamac $\left(27 \mathrm{~m}^{-1}\right)$ reported by Marley et al., [34]. The lower light absorption at Tula compared to both sites results from the single point source behavior of the industrial complex; therefore the plume sweeps the region out according to local winds, and not always reaching the monitoring device. In addition, Marley et al. [39] observed large amounts of biomass burning contributing to carbonaceous aerosols at Tecamac and that Mexico City was significantly impacted by emissions from fossil fuels in addition to local and regional burning.

3.5. Tula-Vito-Apasco Industrial Corridor $\mathrm{SO}_{2}$ Export. Nearly 20 plume transects were measured with a 3 to $8 \mathrm{~h}$ time-spam, for an equivalent distance of 120 to $320 \mathrm{~km}$. The $\mathrm{SO}_{2}$ plume direction was variable during the period of study, mostly affected by meteorology at synoptic scale. The plume's most frequent direction was from southeast after midday, when the wind at the surface was from NNE. Under this condition, the $\mathrm{SO}_{2}$ plume did cross the Mexico-Queretaro highway, SW of the Tula-Vito-Apasco corridor. Other less frequent episodes showed the $\mathrm{SO}_{2}$ dispersion towards the east of the industrial area, which after interacting with the mountain range diminishes the transport of the $\mathrm{SO}_{2}$ plume outside the area.

Figure 1(b) shows the trajectory of the $\mathrm{SO}_{2}$ dispersion plume observed on April 4, at 16:00 and 17:00 h. Two routes that were selected to follow the $\mathrm{SO}_{2}$ plume. The red colored lines show the relative $\mathrm{SO}_{2}$ column concentration measured using the MiniDOAS system. Route 1 was all around the refinery through the southeast. Route 2 includes a northsouth transect from Tula City to Tepeji. The $\mathrm{SO}_{2}$ plume is dispersed along routes 1 and 2 in the southwest direction. The aforementioned dispersion trajectory was the most common, although other less frequent trajectories were also observed.
For instance on April 7, the $\mathrm{SO}_{2}$ plume dispersed through the north and then at midday to the southeast (not shown).

On the other hand, wind roses (Figure 8) of the $\mathrm{SO}_{2}$ concentrations (ppm) were drawn from March 18 and April 17 for the Villa de las Flores (VIF) and La Merced (MER) stations, which are located most north and downtown of Mexico City, respectively. The results showed that highest $\mathrm{SO}_{2}$ concentrations ( 0.10 to $0.25 \mathrm{ppm}$ ) at VIF were associated to northerly wind flows $\left(330^{\circ}-30^{\circ}\right)$. On the other hand, at MER the $\mathrm{SO}_{2}$ concentrations were $25 \%$ lower than those observed at VIF, and the highest values $(>0.02 \mathrm{ppm})$ occurred when winds flows were from the NE-E $\left(45^{\circ}-105^{\circ}\right)$. These results suggest that $\mathrm{SO}_{2}$ emissions from Mezquital Valley have an impact on the northern sector of MCMA. In turn, $\mathrm{SO}_{2}$ concentrations were higher at VIF compared to those measured at JAS $(0.13 \mathrm{ppm})$, implying that the height of the emitted plume from the RTPPC has a higher impact outside the emission point. This is in agreement with model simulations for Tula reported by de Foy et al. [40].

3.6. Long-Term Plume Trajectory. Figure 9 shows the emission plume that develops from the RTPPC as depicted by the higher vanadium and nickel concentrations and ${ }^{13} \mathrm{C}$ depleted carbon values in T. recurvata in Mezquital Valley relative to background. These metal concentrations and carbon isotope composition represent the long-term pattern area of influence of the emissions from the complex and show that it impacts those towns located along a NE-SW axis between Tlaxcoapan and TEP, and further exits out the valley. The highest nickel and vanadium concentrations in $T$. recurvata were equally distributed at both sides of the axis. In contrast, $\delta^{13} \mathrm{C}$ values show lighter values to the east of this axis. Metals are likely emitted with particles and would tend to disperse equally at both sides of the long-wind axis, settling within a relatively short distance from the emitter. In contrast, carbon would be mostly emitted as $\mathrm{CO}_{2}$ and assimilated as such by the epiphyte. It thus appears that gas emissions are influenced by a mountain effect: when wind blows from the SE quadrant the plume disperses into the valley and dilutes the emitted $\mathrm{CO}_{2}$. In contrast, when the wind direction is from the NW or NE quadrants, emissions tend to concentrate between the RTPPC and the mountain chain located to the S-SE of the complex. Therefore, the relatively longer residence time of the emissions under NW or NE quadrant winds lowers the ambient carbon isotope composition of $\mathrm{CO}_{2}$.

The relative contribution of $\mathrm{CO}_{2}$ emitted by the RTPPC can be estimated from the average $\delta^{13} \mathrm{C}$ value of the epiphyte. The carbon isotope composition of $T$. recurvata decreased from an average of $-14.6 \%$ outside the emitted plume to $-15.4 \%$ inside the plume. This $1.8 \%$ decrease suggests that industrial emissions contribute with $5 \%$ of the total $\mathrm{CO}_{2}$ incorporated by $T$. recurvata inside the plume. By stable isotope-mass balance, it follows that industrial $\mathrm{CO}_{2}$ has a $\delta^{13} \mathrm{C}$ value of $-30.0 \%$, which is consistent with the range of -29.5 to $-27.6 \%$ for $\mathrm{CO}_{2}$ emitted for the combustion of diesel and fuel oil [41]. Considering a fractionation $(\Delta)$ of $-1.3 \%$ between the fuel source and the emitted $\mathrm{CO}_{2}[41]$, 


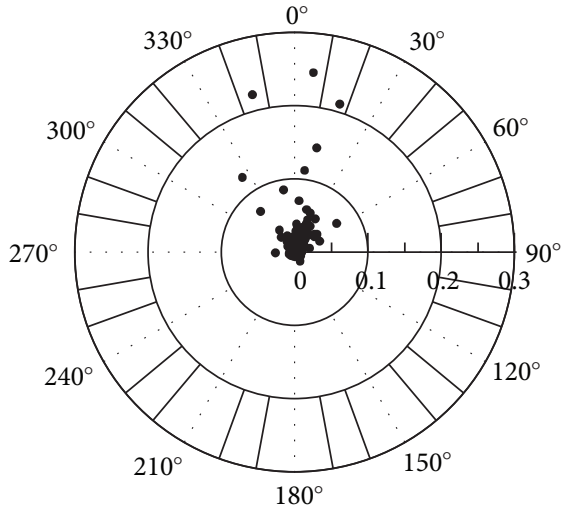

Villa de las Flores

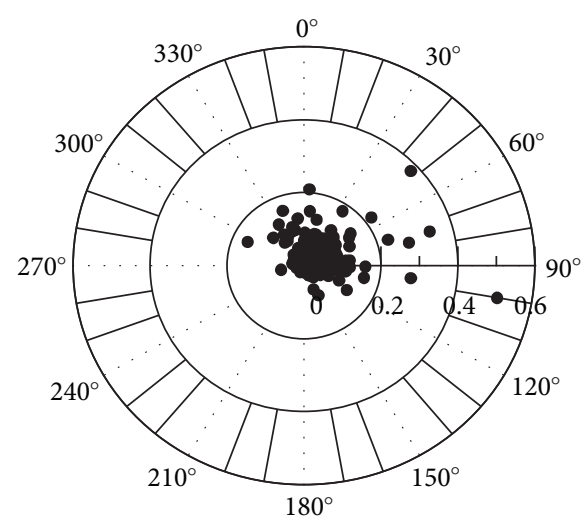

Merced

FIGURE 8: Wind roses of the $\mathrm{SO}_{2}$ concentrations (ppm) for the Villa de las Flores (VIF) and La Merced (MER) stations from 18 of March and 17 of April.

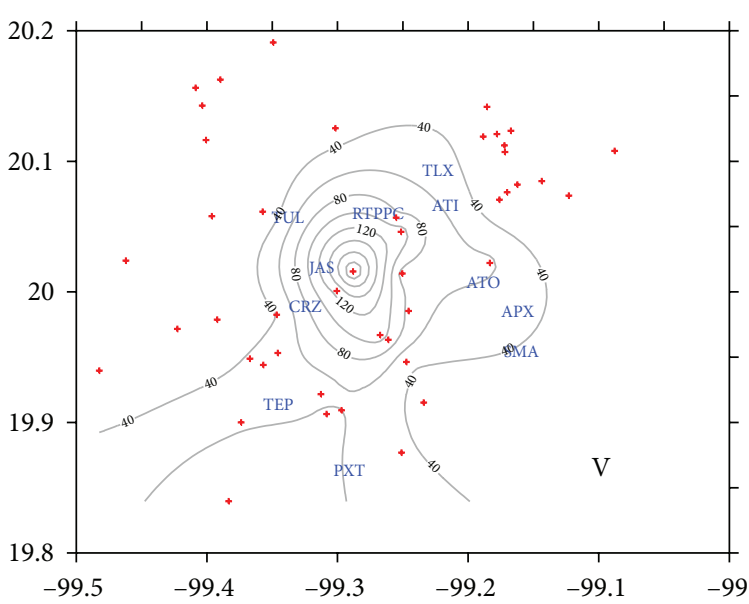

(a)

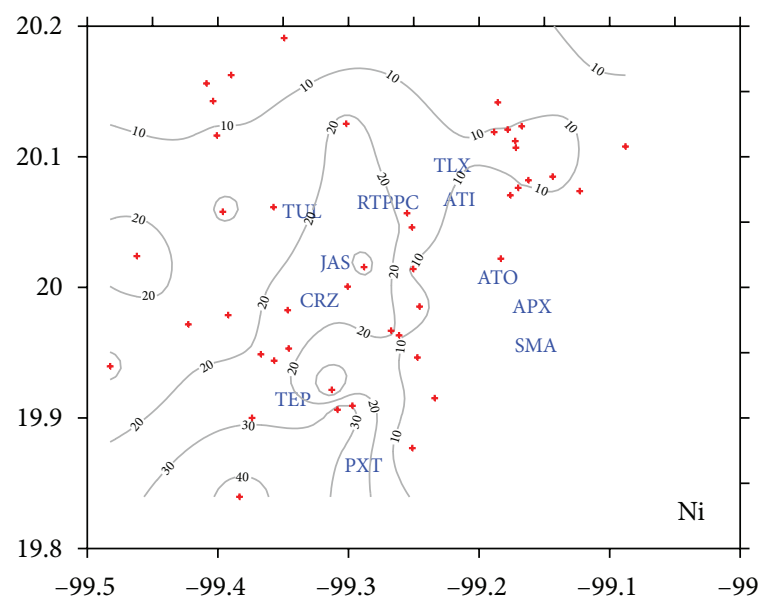

(b)

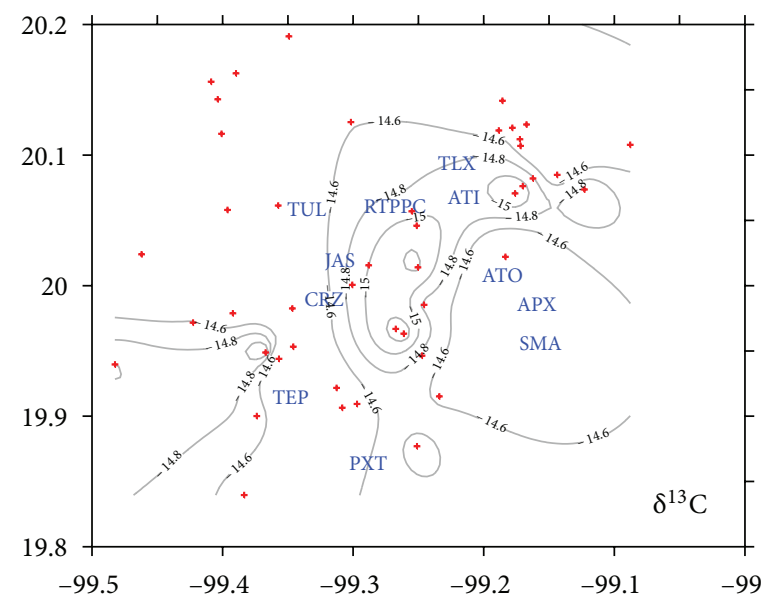

(c)

Figure 9: Nickel and vanadium concentrations (in $\mathrm{mg} / \mathrm{kg}$ ) and stable carbon isotope composition (in permile versus PDB) in Tillandsia recurvata samples collected in Mezquital Valley. 
then the carbon isotope composition of the fuel used by the RTPPC is around $-28.7 \%$.

\section{Conclusions}

The results of four-week monitoring campaign of particulate matter and gaseous pollutants, as well as meteorological parameters are presented. The present study was conducted in one of the most industrial energy-intense production corridors of Mexico, located $60 \mathrm{~km}$ north of Mexico City. The databases are also meant to be used as inputs for future modeling studies and to quantitatively determine the influence of emissions of this region on the air quality in the northern area of MCMA.

Early in the morning a shallow stable layer is formed, with light south-southwesterly winds. These conditions favor accumulation of air pollutants below $100 \mathrm{~m}$ and with a limited dispersion of pollutants towards the north of Tula. After midday, a well developed mixing layer is observed up to $1500 \mathrm{~m}$, favoring the mixing of pollutants at higher altitudes. In addition, a superadiabatic layer near the surface, with a clear northern wind component, brings back the pollutants that were transported northward early in the morning. In the afternoon and evening, a similar vertical atmospheric profile is observed; a thicker mixing layer reaches in average 2500 to $3000 \mathrm{~m}$, and a featuring weak low level jet responsible of transporting air pollutants at regional scales. According to the authors' knowledge, this is the first time this feature is reported for this region.

The results of the criteria pollutants concentration at TUL showed that during the study period, most of the pollutants were found to be below the standards, except for $\mathrm{PM}_{10}$ and $\mathrm{SO}_{2}$ that were above the limits twice and $\mathrm{O}_{3}$ once in each case. Nonetheless, the spatial distribution of these pollutants varies according to location and time of the day. The highest concentrations of $\mathrm{O}_{3}$ and $\mathrm{SO}_{2}$ were measured at the southeast of the refinery within a distance of more than $15 \mathrm{~km}$.

Elevated $\mathrm{PM}_{10}$ concentrations $\left(178.6 \mu \mathrm{g} / \mathrm{m}^{3}\right)$ exceeding the standard measured at the urban-industrial site of JAS were associated to the increase of wind speeds up to $8.0 \mathrm{~m} / \mathrm{s}$. Additionally, this site was highly impacted by local limestone dust since the coarse fraction ranged from 40 to $79 \%$ with an average of $56 \%$. Preliminary results from chemical analysis showed that high $\mathrm{PM}_{10}$ concentrations were driven by calcium mainly due limestone mining for cement materials and limestone quarries nearby JAS and in the surroundings of Tula, whilst in Mexico City, it is driven by silicon. $\mathrm{PM}_{10}$ levels at TEP showed an average of $75.1 \mu \mathrm{g} / \mathrm{m}^{3}$, while the $\mathrm{PM}_{2.5}$ average was $25.7 \mu \mathrm{g} / \mathrm{m}^{3}$, and an average $\mathrm{PM}_{10} / \mathrm{PM}_{2.5}$ mass ratio of 0.68 indicating that almost $70 \%$ of the $\mathrm{PM}_{10}$ are constituted by $\mathrm{PM}_{2.5}$. The above suggests that this site was influenced by higher emission from fossil fuel combustion processes from the refinery and the power plant, among other sources in the vicinity.

$\mathrm{PM}_{2.5}$ concentrations were influenced by a peak recorded during the morning, similar to the continuous black carbon measurements, which agrees with a recurrent stable layer formed near the surface before 8:00 $\mathrm{h}$ and light winds favoring particle accumulation.

Average hourly aerosol light absorption was $22 \mathrm{Mm}^{-1}$ which is smaller compared to both urban and rural sites. Average hourly aerosol scattering $\left(76 \mathrm{Mm}^{-1}\right)$ was higher compared to a rural site but much lower than at Mexico City. Elevated values were related to uncommon flaring activities in the refinery in addition to changes in the boundary layer height. High scattering values were associated to a persistent shallow stable atmospheric layer which traps most primary pollutants emitted close to the surface. Low scattering values were related to the development of the mixing layer favoring the dilution of air pollutants.

Elevated BC concentrations were inversely coincident with the wind speed peak with light winds as the boundary layer is stable favoring stagnation of pollutants. In addition, the decrease of the 1/WS favored dilution of pollutants with the lowest levels of BC.

Stable carbon isotope measurements in the biomonitor species Tillandsia recurvata provide the long-term signature of pollutant dispersion in the region. Results show that the emission plume from the refinery and nearby thermoelectric power plant directly affects the SE sector of Mezquital Valley where the plume is directed by the prevalent winds and then constrained by a mountain range preventing its fast dispersion. Using stable isotope-mass balance, the carbon contribution as $\mathrm{CO}_{2}$ near the emission source to this epiphyte is estimated at around $5 \%$ of the total assimilated by the plant.

The population in this region is exposed to a multipollutant environment, including high levels of sulfur dioxide, submicrometric particles, and black carbon. In addition, frequent adverse meteorological conditions in the morning may exacerbate acute and chronic exposition to these pollutants. The influence of emissions from the RTPPC also affects, to a less extent, the population of MCMA's northern sector. The above-mentioned results evidence the need to establish a contingency plan to avoid population exposure to high concentrations of pollutants in addition to the reduction in industrial emissions to improve wellbeing. Studies within the area that determine the impacts of specific particulate constituents and sources are needed for the effective design of air quality control policies. Finally, a continuous monitoring of both criteria pollutants and meteorological parameters along the Tula-Vito-Apasco corridor is needed to support actions considered in the contingency plan and to better understand impacts of industrial activities on human and ecosystems health.

\section{Conflict of Interests}

Authors do not have any conflict of interests to declare.

\section{Acknowledgments}

The authors gratefully acknowledge the support of PEMEX under Contract IMP-UAJ-DC-018-2006 and Dr. Judith Chow from the Dessert Research Institute for lending them the SFS equipments for the study. 


\section{References}

[1] G. E. Streit and F. Guzman, "Mexico City air quality: progress of an international collaborative project to define air quality management options," Atmospheric Environment, vol. 30, no. 5, pp. 723-733, 1996.

[2] S. A. Edgerton, X. Bian, J. C. Doran et al., "Particulate air pollution in Mexico City: a collaborative research project," Journal of the Air and Waste Management Association, vol. 49, no. 10, pp. 1221-1229, 1999.

[3] L. T. Molina and M. J. Molina, Air Quality in the Mexico Megacity. An Integrated Assessment, Kluwer Academic, Dodrecht, The Netherlands, 2002.

[4] L. T. Molina, C. E. Kolb, B. De Foy et al., "Air quality in North America's most populous city-overview of the MCMA-2003 campaign," Atmospheric Chemistry and Physics, vol. 7, no. 10, pp. 2447-2473, 2007.

[5] C. Rivera, G. Sosa, H. Wöhrnschimmel, B. De Foy, M. Johansson, and B. Galle, "Tula industrial complex (Mexico) emissions of $\mathrm{SO}_{2}$ and $\mathrm{NO}_{2}$ during the MCMA 2006 field campaign using a mobile mini-DOAS system," Atmospheric Chemistry and Physics, vol. 9, no. 17, pp. 6351-6361, 2009.

[6] M. A. Martínez-Carrillo, C. Solís, K. Isaac-Olive, E. Andrade, R. I. Beltrán-Hernández, G. Martínez-Reséndiz et al., "Atmospheric elemental concentration determined by ParticleInduced X-ray emision at Tlaxcoapan in central Mexico, and its relation to Tula industrial-corridor emissions," Microchemical Journal, vol. 94, pp. 48-52, 2010.

[7] C. A. Pope and D. W. Dockery, "Health effects of fine particulate air pollution: lines that connect," Journal of the Air and Waste Management Association, vol. 56, no. 6, pp. 709-742, 2006.

[8] F. Dominici, R. D. Peng, M. L. Bell et al., "Fine particulate air pollution and hospital admission for cardiovascular and respiratory diseases," Journal of the American Medical Association, vol. 295, no. 10, pp. 1127-1134, 2006.

[9] M. L. Bell, F. Dominici, K. Ebisu, S. L. Zeger, and J. M. Samet, "Spatial and temporal variation in $\mathrm{PM}_{2.5}$ chemical composition in the United States for health effects studies," Environmental Health Perspectives, vol. 115, no. 7, pp. 989-995, 2007.

[10] F. Dominici, R. D. Peng, K. Ebisu, S. L. Zeger, J. M. Samet, and M. L. Bell, "Does the effect of $\mathrm{PM}_{10}$ on mortality depend on PM nickel and vanadium content? A reanalysis of the NMMAPS data," Environmental Health Perspectives, vol. 115, no. 12, pp. 1701-1703, 2007.

[11] A. R. Osornio-Vargas, J. C. Bonner, E. Alfaro-Moreno et al., "Proinflammatory and cytotoxic effects of Mexico City air pollution particulate matter in vtro are dependent on particle size and composition," Environmental Health Perspectives, vol. 111, no. 10, pp. 1289-1293, 2003.

[12] I. Rosas Pérez, J. Serrano, E. Alfaro-Moreno et al., "Relations between $\mathrm{PM}_{10}$ composition and cell toxicity: a multivariate and graphical approach," Chemosphere, vol. 67, no. 6, pp. 1218-1228, 2007.

[13] E. M. Melgar-Paniagua, E. Vega-Rangel, L. M. Del Razo, C. A. Lucho-Constantino, S. J. Rothenberg, and A. De VizcayaRuiz, "Distributed lag associations between respiratory illnesses and mortality with suspended particle concentration in Tula, a highly polluted industrial region in Central Mexico," International Archives of Occupational and Environmental Health, April 2012.

[14] B. de Foy, N. A. Krotkov, N. Bei et al., "Hit from both sides: tracking industrial and volcanic plumes in Mexico City with surface measurements and $\mathrm{OMI} \mathrm{SO}_{2}$ retrievals during the MILAGRO field campaign," Atmospheric Chemistry and Physics, vol. 9, no. 24, pp. 9599-9617, 2009.

[15] V. H. Almanza, L. T. Molina, and G. Sosa, "Soot and $\mathrm{SO}_{2}$ contribution to the supersites in the MILAGRO campaign from elevated flares in the Tula Refinery," Atmospheric Chemistry and Physics, vol. 12, pp. 10583-10599, 2012.

[16] Secretaría del Medio Ambiente, "Inventario de emisiones 2006. SMA- GDF," 2006.

[17] Instituto Mexicano del Petróleo, "Estudio de las emisiones de la zona industrial de Tula y su impacto en la calidad del aire regional," PS-MA-IF-F21393-1, 2006.

[18] H. Tennekes, “The atmospheric boundary layer," Physics Today, vol. 27, no. 1, pp. 52-63, 1974.

[19] E. Vega, E. Reyes, H. Ruiz, J. García, G. Sánchez, G. MartínezVilla et al., "Analysis of $\mathrm{PM}_{2.5}$ and $\mathrm{PM}_{10}$ in Mexico City atmosphere during 2000-2002," Journal of the Air \& Waste Management Association, vol. 54, pp. 786-798, 2004.

[20] M. E. Conti and G. Cecchetti, "Biological monitoring: lichens as bioindicators of air pollution assessment-a review," Environmental Pollution, vol. 114, no. 3, pp. 471-492, 2001.

[21] G. J. Husk, J. F. Weishampel, and W. H. Schlesinger, "Mineral dynamics in Spanish moss, Tillandsia usneoides L. (Bromeliaceae), from Central Florida, USA," Science of the Total Environment, vol. 321, no. 1-3, pp. 165-172, 2004.

[22] A. Zambrano García, C. Medina Coyotzin, A. Rojas Amaro, D. López Veneroni, L. Chang Martínez, and G. Sosa Iglesias, "Distribution and sources of bioaccumulative air pollutants at Mezquital Valley, Mexico, as reflected by the atmospheric plant Tillandsia recurvata L.," Atmospheric Chemistry and Physics, vol. 9, no. 17, pp. 6479-6494, 2009.

[23] Instituto Nacional de Ecología (INE), Campaña de monitoreo de calidad del aire de la Región Tula-Tepeji-Zumpango del 20 de Octubre al 5 de Diciembre del 2008, 2009.

[24] J. D. Fast, B. De Foy, F. A. Rosas et al., "A meteorological overview of the MILAGRO field campaigns," Atmospheric Chemistry and Physics, vol. 7, no. 9, pp. 2233-2257, 2007.

[25] Y. Wu and S. Raman, "Effect of land-use pattern on the development of low-level jets," Journal of Applied Meteorology, vol. 36, no. 5, pp. 573-590, 1997.

[26] Comisión Federal para la Protección contra Riesgos Sanitarios (Cofepris), "Mexican Oficial Standards for Criteria Pollutants," 2010, http://www.cofepris.gob.mx/MJ/Paginas/ NormasPorTema/Calidad-de-aire.aspx.

[27] Diario Oficial de la Federación, "Modificación a la Norma Oficial Mexicana NOM-025-SSA1-1993, Salud ambiental," Criterios para evaluar la calidad del aire ambiente, con respecto a material particulado, 2005.

[28] X. Querol, J. Pey, M. C. Minguillón, N. Pérez, A. Alastuey, M. Viana et al., "PM speciation and sources in Mexico during the MILAGRO-2006 Campaign," Atmospheric Chemistry and Physics, vol. 8, pp. 111-128, 2008.

[29] E. Vega, H. Ruiz, G. Martínez-Villa et al., "Fine and coarse particulate matter chemical characterization in a heavily industrialized city in Central Mexico during Winter 2003," Journal of the Air and Waste Management Association, vol. 57, no. 5, pp. 620-633, 2007.

[30] G. Paredes-Miranda, W. P. Arnott, J. L. Jimenez, A. C. Aiken, J. S. Gaffney, and N. A. Marley, "Primary and secondary contributions to aerosol light scattering and absorption in Mexico City during the MILAGRO 2006 campaign," Atmospheric Chemistry and Physics, vol. 9, no. 11, pp. 3721-3730, 2009. 
[31] Secretaría de Salud, Panorama Epidemiológico de la Región Tula-Tepeji, Hidalgo, Comisión para la Protección contra Riesgos Sanitarios del Estado de Hidalgo (COPRISEH), Subcomisión de Evidencia, Manejo de Riesgos y Trámites. Secretaría de Salud de Hidalgo, 2008.

[32] M. J. Strickland, L. A. Darrow, M. Klein et al., "Short-term associations between ambient air pollutants and pediatric asthma emergency department visits," American Journal of Respiratory and Critical Care Medicine, vol. 182, no. 3, pp. 307-316, 2010.

[33] R. D. Peng, M. L. Bell, A. S. Geyh et al., "Emergency admissions for cardiovascular and respiratory diseases and the chemical composition of fine particle air pollution," Environmental Health Perspectives, vol. 117, no. 6, pp. 957-963, 2009.

[34] N. A. Marley, J. S. Gaffney, T. Castro, A. Salcido, and J. Frederick, "Measurements of aerosol absorption and scattering in the Mexico City Metropolitan Area during the MILAGRO field campaign: a comparison of results from the T0 and T1 sites," Atmospheric Chemistry and Physics, vol. 9, no. 1, pp. 189-206, 2009.

[35] G. Buonanno, G. Giovinco, L. Morawska, and L. Stabile, "Corrigendum to 'Tracheobronchial and alveolar dose of submicrometer particles for different population age groups in Italy,' Atmospheric Environment, vol. 45, pp. 6216-6224, 2011.

[36] G. Buonanno, G. Giovinco, L. Morawska, and L. Stabile, "Corrigendum to 'Tracheobronchial and alveolar dose of submicrometer particles for different population age groups in Italy"', Atmospheric Environment, vol. 49, p. 423, 2012.

[37] A. D. A. Hansen, The Aethalometer, Magee Scientific Company, Berkeley, Calif, USA, 2003.

[38] R. W. Bergstrom, P. Pilewskie, P. B. Russell et al., "Spectral absorption properties of atmospheric aerosols," Atmospheric Chemistry and Physics, vol. 7, no. 23, pp. 5937-5943, 2007.

[39] N. A. Marley, J. S. Gaffney, M. Tackett, N. C. Sturchio et al., "The impact of biogenic carbon sources on aerosol absorption in Mexico City," Atmospheric Chemistry and Physics, vol. 9, pp. 1537-1549, 2009.

[40] B. de Foy, W. Lei, M. Zavala et al., "Modelling constraints on the emission inventory and on vertical dispersion for $\mathrm{CO}$ and $\mathrm{SO}_{2}$ in the Mexico City Metropolitan Area using Solar FTIR and zenith sky UV spectroscopy," Atmospheric Chemistry and Physics, vol. 7, no. 3, pp. 781-801, 2007.

[41] D. Widory, "Combustibles, fuels and their combustion products: a view through carbon isotopes," Combustion Theory and Modelling, vol. 10, no. 5, pp. 831-841, 2006. 

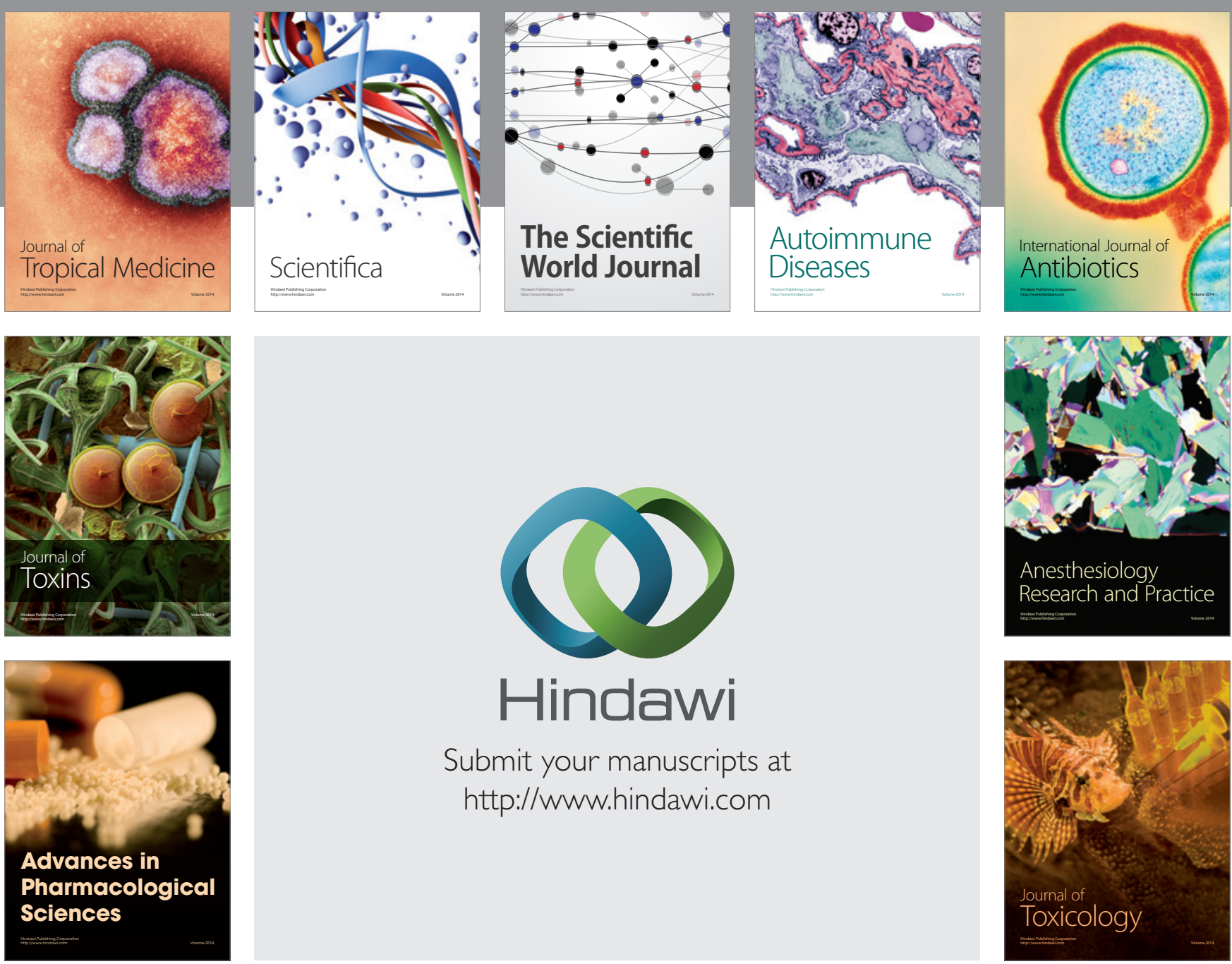

\section{Hindawi}

Submit your manuscripts at

http://www.hindawi.com
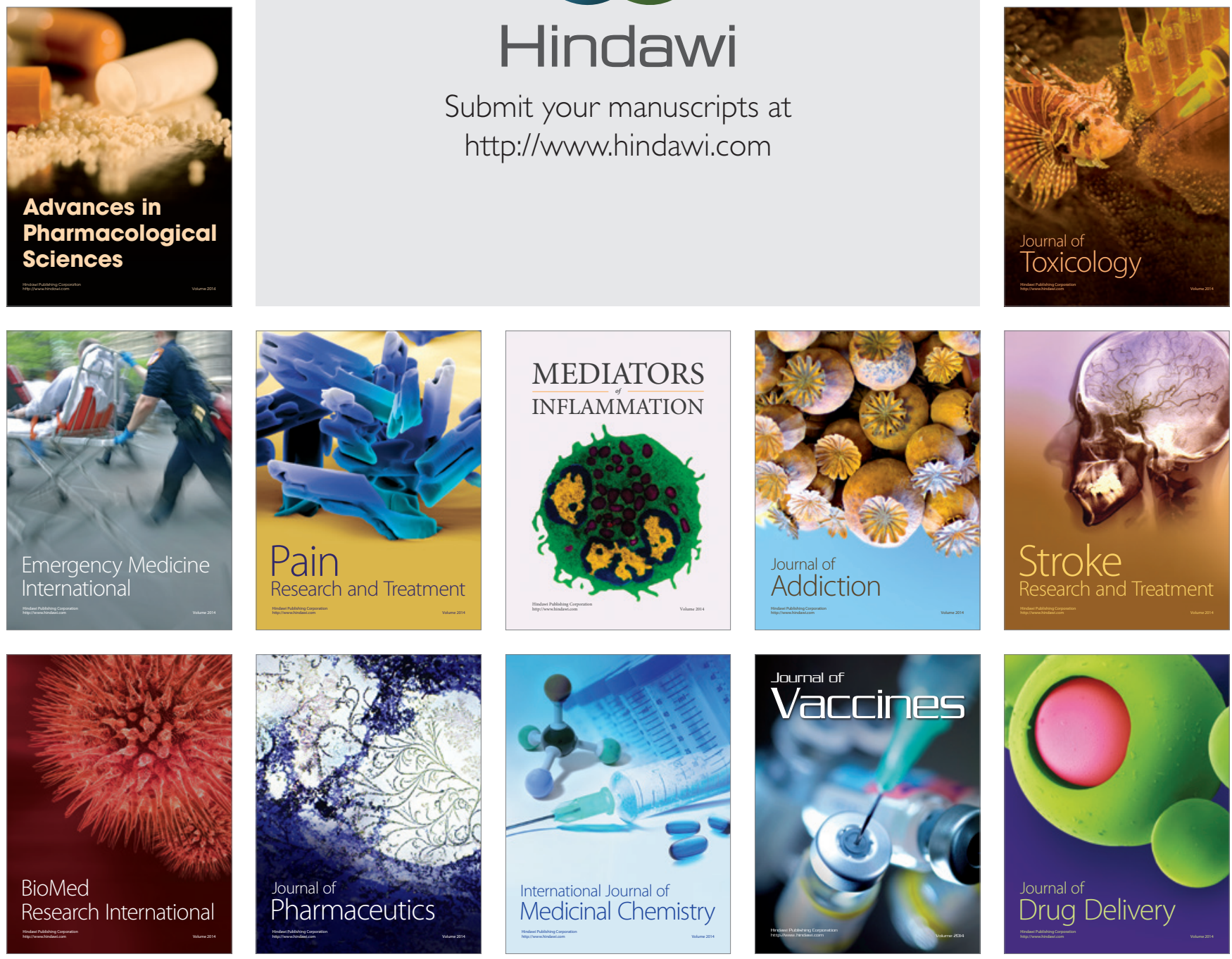